\title{
Hip arthroplasty in patients with high hip dislocation using a device for shortening subtrochanteric osteotomy of the femur
}

\author{
A.S. Triapichnikov, B.V. Kamshilov, O.P. Zaitseva, O.K. Chegurov, Ya.V. Evreinova, M.Yu. Frashko \\ Ilizarov National Research Centre for Orthopaedics and Traumatology, Kurgan, Russian Federation
}

\begin{abstract}
Introduction Hip joint arthroplasty combined with shortening osteotomy is a technically difficult surgical intervention. Transection of the femur is possible both with the free-hand method and with the use of special devices. Purpose To evaluate the efficiency of using a special device for shortening osteotomy in total hip arthroplasty in comparison with the operations performed without an osteotomy guide. Materials and methods There were 16 hip replacement surgeries that included shortening osteotomy performed in patients with high dislocation of the femur. The group was divided into 2 subgroups: the study subgroup (8 cases), in which a special device was used for osteotomy, and the control subgroup (8 cases). We used clinical and radiographic study methods, and assesssed the Harris Hip Score (HHS) before and after treatment. Results Duration of the intervention and intraoperative blood loss in the first subgroup were shorter than in the control group but the difference was not statistically significant. The mean HHS increased significantly in the whole group. The midterm HHS in the study subgroup was $85.4 \pm 1.9$ points, which slightly differed from the control ( $81.9 \pm 1.2$ points). The mean followup period was $40 \pm 8$ months. There were two cases of nonunion in the osteotomy site and one case of transient sciatic neuropathy. Two patients with nonunion of the femoral fragments were treated by plating and bone grafting. Conclusion The use of a special device for subtrochanteric osteotomy technically simplifies the arthroplasty procedure in patients with high dislocation of the femur, shortens the operation time and reduces blood loss.
\end{abstract}

Keywords: hip arthroplasty, hip dislocation, shortening subtrochanteric osteotomy, femur, device for osteotomy

\section{INTRODUCTION}

Hip joint arthroplasty in patients with congenital hip disclocation is a technically difficult surgical intervention [1-7]. Shortening osteotomy is frequently a need for bringing the proximal femur down to a required distance to install the cup into the true acetabulum. It reduces the risk of neurological complications and excludes tension of the surrounding muscles and other soft tissues [1, $3,8-11]$. Several variants of the intervention were described: subtrochanteric osteotomy, Paavilainen proximal osteotomy [12-14], and distal osteotomy of the femur which has been rarely used $[15,16]$.

The femur can be broken with several techniques, including transverse, oblique, step-like and double chevron osteotomy $[5,6,17,18]$. There are no persuading arguments in favour of technically complex osteotomies over the transverse one [19]. However, two parallel transverse osteotomies and resection of the fragment of a definite length should be produced for maximum contact of the femoral fragments and avoid nonunion risk. The manipulation can be perfomed both with the method of "free hand" or special devices.

Purpose To assess the validity of a special device for shortening osteotomy of the femur in total hip arthroplasty and to compare the outcomes with the intenvention performed without any osteotomy guide.

\section{MATERIAL AND METHODS}

Sixteen patients (16 hips) with high dislocation of the femur who were treated between 2014 and 2019 were included into the study. Including criteria were Crowe type IV hip dysplasia and the need for shortening osteotomy of the femur while performing total hip arthroplasty. Systemic or local infection and somatic contraindications were exlusion criteria. All patients were females in the mean age of $38.6 \pm 2$ years (range, $25-55$ years). Mean relative limb shortening before the intervention was
$5.34 \pm 0.3 \mathrm{~cm}(\min -4 \mathrm{~cm}, \max -6.5 \mathrm{~cm})$. The whole group was devided into two subgroups: study subgroup and control subgroup (Table 1).

The study subgroup included eight patients in whom shortening osteotomy was produced with a guiding device (RF patent No. 182499). Figure 1 shows the guiding device fixed to a dry femoral bone before producing subtrochanteric osteotomy. The osteotomy was performed without a guide in the control subgroup.

[1 Triapichnikov A.S., Kamshilov B.V., Zaitseva O.P., Chegurov O.K., Evreinova Ya.V., Frashko M.Yu. Hip arthroplasty in patients with high hip dislocation using a device for shortening subtrochanteric osteotomy of the femur. Genij Ortopedii, 2020, vol. 26, no 4, pp. 484-488. DOI 10.18019/1028-4427-2020-26-4-484-488 
Table 1 treated with raspatories upon completion of femoral

Characteriscts of the patients

\begin{tabular}{|l|c|c|c|}
\hline & Total group & $\begin{array}{c}\text { Study } \\
\text { subgroup }\end{array}$ & $\begin{array}{c}\text { Control } \\
\text { subgroup }\end{array}$ \\
\cline { 2 - 4 } & $\mathrm{N}=16$ & $\mathrm{~N}=8$ & $\mathrm{~N}=8$ \\
\hline Age & $38.6 \pm 2$ & $37.2 \pm 1.9$ & $40.1 \pm 1.9$ \\
\hline $\begin{array}{l}\text { Mean relative limb } \\
\text { shortening (cm) }\end{array}$ & $5.34 \pm 0.3$ & $4.9 \pm 0.25$ & $5.7 \pm 0.3$ \\
\hline $\begin{array}{l}\text { Length of the resected } \\
\text { fragment (cm) }\end{array}$ & $3.25 \pm 0.15$ & $3.2 \pm 0.1$ & $3.3 \pm 0.2$ \\
\hline $\begin{array}{l}\text { Harris Hip } \\
\text { Score before the } \\
\text { intervention (points) }\end{array}$ & $38.1 \pm 1.5$ & $39.8 \pm 0.9$ & $40.8 \pm 1.3$ \\
\hline
\end{tabular}

Note: $\mathrm{N}$ - number of cases
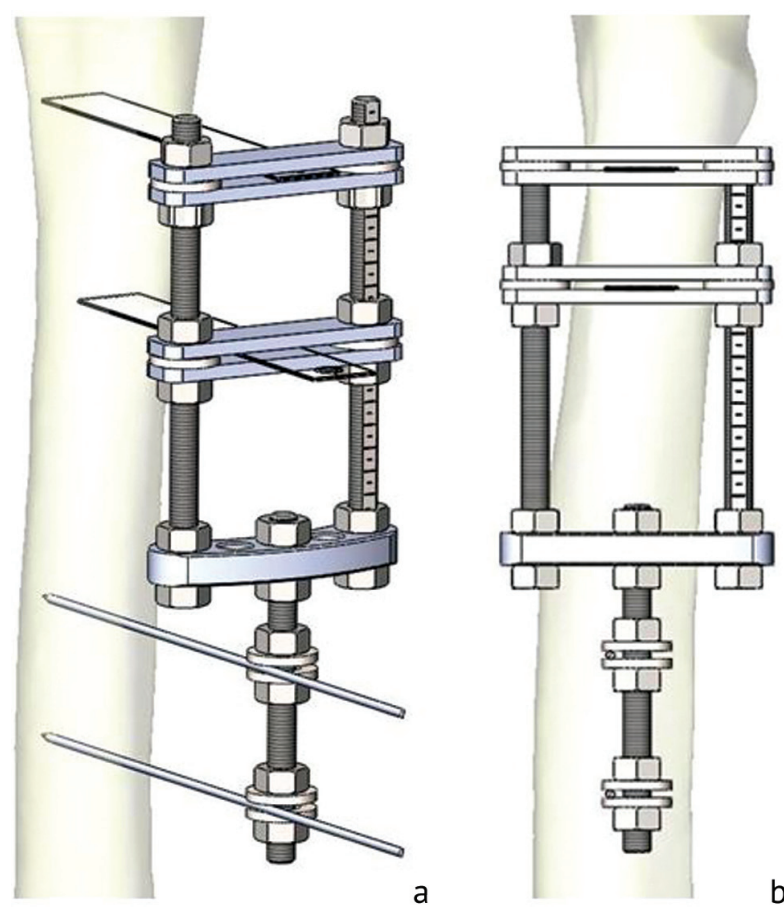

Fig 1 Guiding device for osteotomy: $\boldsymbol{a}$ lateral view; $\boldsymbol{b}$ front view

The study was approved by the ethics board of the NIMRC for TO. Cementless Smith\&Nephew or Zimmer implants with conical stems of square-angled section were used in arthroplasty. Plating was used in two cases for osteosynthesis of a periprosthetic fracture and nonunion of the femur in the osteotomy zone.

Surgical technique The Harding approach extended distally was used. The femur canal was neck osteotomy. Having mobilised the soft tissues distal to the lesser trochanter with a raspatory, the guiding device was fixed to the femur with two wires inserted transcortically (Fig. 1). Next, the shortening osteotomy followed. The proximal fragment of the femur was displaced backwards to increase the approach to the acetabulum.

The cup was implanted considering the hypoplastic edges and specific shape of the acetabulum which are characteristic of the Crowe type IV dysplasia [1]. One to three crews were used for additional fixation of the cup in $75 \%$ of cases.

The femur component was implanted according to the technique described [20]. If the contact of the fragments was not satisfactory, a corrective osteotomy was produced additionally to improve the contact of the fragments.

When a stable joint with a satisfactory range of motion and without excessive soft tissue tensioning had been achieved, the femoral component was implanted. Plating was used in five cases $(27.7 \%)$ in doubtful stability of fixation of the femoral fragments.

Clinical and radiographic evaluation

Harris Hip Score was used for functional assessment before and after the operation. Lower limb telemetria capturing the illiac wings down to the ankle joint was used in 14 cases. CT was performed in ten cases preoperatively to visualise the spatial ralations in the hip. Radiological methods also evaluated the position of the implant components and consolidation of the femoral fragments. The shift of the rotation centre was determined analysing the radiographs. The change in the limb length after the intervention was checked clinically and telemetrically.

Moreover, the head-to-neck offset before and after the arthroplasty, the angle of inclination of the acetabular component, vertical and horizontal centre of rotation of the acetabular component were evaluated.

StatSoft Statistica 13.0 and Microsoft EXCEL 2010 were used for statistical processing. Wilcoxon nonparametric test defined the significance of differences. The diffence was judged significant at $p \leq 0.05$.

\section{RESULTS}

All 16 cases $(100 \%)$ were followed up for eight to 48 months (mean, $40.8 \pm 2.4$ months). Mean duration of the intervention was $205 \pm 12.2$ minutes (range, 90-290 minutes). Intraoperaive blood los was $763 \pm 41 \mathrm{ml}$ (range, 300-1100 ml). Peoperative HHS was $38.1 \pm 1.5$ points ( $\min -30.9$ points, $\max -$ 49.5 points). Radiography and clinical tests showed that the femur consolidated in the osteotomy site after a mean of $6.8 \pm 0.3$ months (range, 6-8 months). Repeated surgeries using plating and bone allografting were required in two patients $(12.5 \%)$ due to femur nonunion. Main parameters of the intervention are given in Table 2.

Mean total inpatient time was $20.5 \pm 1.4$ days (range, 14-50 days), $18.5 \pm 1.3$ days in the study subgroup and $22.7 \pm 1.5$ days in the control subgroup. Relative limb length increased after the intervention by $3.34 \pm 0.28 \mathrm{~cm}$ $(\min -2.1 \mathrm{~cm}, \max -5.0 \mathrm{~cm})$. Mean offset increased by $0.2 \pm 0.03 \mathrm{~cm}(\min -0.05 \mathrm{~cm}, \max -0.22 \mathrm{~cm})$ (Table 3$)$. 
Table 2

Parameters of surgical intervention and HHS in the groups

\begin{tabular}{|l|c|c|c|}
\hline & Total group & Study subgroup & Control subgroup \\
\cline { 2 - 4 } & $\mathrm{n}=16$ & $\mathrm{n}=8$ & $\mathrm{n}=8$ \\
\hline Intraoperative blood loss $(\mathrm{ml})$ & $763 \pm 41$ & $725 \pm 48.5$ & $807 \pm 30$ \\
\hline Duration of the intervention (min) & $205 \pm 12.2$ & $180.6 \pm 12.6$ & $229.3 \pm 8.4$ \\
\hline Harris Hip Score after the intervention (points) & $83.4 \pm 1.8$ & $85.4 \pm 1.9$ & $81.9 \pm 1.2$ \\
\hline
\end{tabular}

Note: $\mathrm{N}$ - number of patients

Table 3

Main radiographic parameters in the group

\begin{tabular}{|l|c|c|c|}
\hline & Total group & Study subgroup & Control subgroup \\
\cline { 2 - 4 } & $\mathrm{n}=16$ & $\mathrm{n}=8$ & $\mathrm{n}=8$ \\
\hline Increase in the postoperative offset $(\mathrm{mm})$ & $0.2 \pm 0.03$ & $0.18 \pm 0.02$ & $0.21 \pm 0.1$ \\
\hline Angle of acetabular component inclination(degrees) & $36.2 \pm 1.3$ & $34.5 \pm 1.6$ & $38.2 \pm 1.8$ \\
\hline Vertical rotation centre of the acetabular component & $15.3 \pm 1$ & $14.3 \pm 0.9$ & $16.3 \pm 1$ \\
\hline Horizontal rotation centre of the acetabular component & $28.8 \pm 0.5$ & $28.5 \pm 0.7$ & $29 \pm 0.8$ \\
\hline
\end{tabular}

Note: $\mathrm{N}$ - number of patients

Mean HHS in the whole group was $83.4 \pm 1.8$ points and was significantly different from the initial value $(p=0.013)$. Differences between postoprative and preoperative scores in the study and control subgroups were also significant $(\mathrm{p}=0.017$ and $\mathrm{p}=0.014)$. Midterm HHS in the study subgroup was $85.4 \pm 1.9$ points and $81.9 \pm 1.2$ points in the control subgroup. The scores differed significantly $(\mathrm{p}=0.09)$. Fourteen patients $(87.5 \%)$ had HHS over 80 points that corresponded to a good functional outcome.

Duration of the intervention in the study subgroup was less than in the control one. Intraoperaive blood loss was also lower (Table 2). However, the differences were not statistically significant, $\mathrm{p}=0.1$ and $\mathrm{p}=0.44$, respectively.

Complications and re-operations The distal fragment of the femur broke intraoperatively by installation of the implant in two patients. Cerclage was used for osteosynthesis and the femurs consoldated later. One patient in the control subgroup had transient neuropathy. Clinical symptoms were relieved by application of temporal epineural electrodes and neurotropic therapy.

Two patients, one from each subgroup, had nonunion between the proximal and distal fragments of the femur in the osteotomy site. The nonunion was revealed radiographically at a follow-up after seven and nine months following arthroplasty. Aseptic instability of the femoral component was not detected. Thus, the re-operation included plating and bone grafting. Plates were removed after consolidation in both cases. Radiographic and clinical examination did not reveal signs of aseptic instability of the femoral components.

\section{DISCUSSION}

There are various techniques of subtrochanteric osteotomy performance $[5,17,18]$. Almost all the publications available describe the performance of both transverse and oblique osteotomies, along with more complex ones such as chevron and step-cut osteotomies by using the method of "free hand" without special devices [5, 6, 17, 18, 21-25]. However, the "free hand" technique does not always provide a good contact between the femoral fragments that might result in delayed consolidation or even be a reason of nonunion $[2,6,9,17,22,25]$.

Only the work of Hotokebuchi et al describes double chevron osteotomy with the use of an original device (Fig. 2) [26].

However, the device described provides the performance of double-chevron (V-shaped) osteotomy only and does not allow rotation of fragments after primary bone sawing. Moreover, only a variation resection step of 5-mm is possible with the use of this device.

The use of the device patented by us enables correct bone sawing. It also assisted in reducing the duration of the arthroplasty intervention that included the shortening osteotomy and intraoperative blood loss. The differences were not significant $(p>0.05)$, but we believe that it is associated with a small number of patients.

Only one study with the use of a special device for performingsubtrochanteric osteotomy inhip arthroplasty has been found by us in the available literature. The results of its authors do not allow conclusions on the efficiency of the method in comparison with the method of "free hand". The data presented in Table 4 prove that nonunion of the femoral fragments in the osteotomy site and traction neuropathies are typical complications after such operations. 

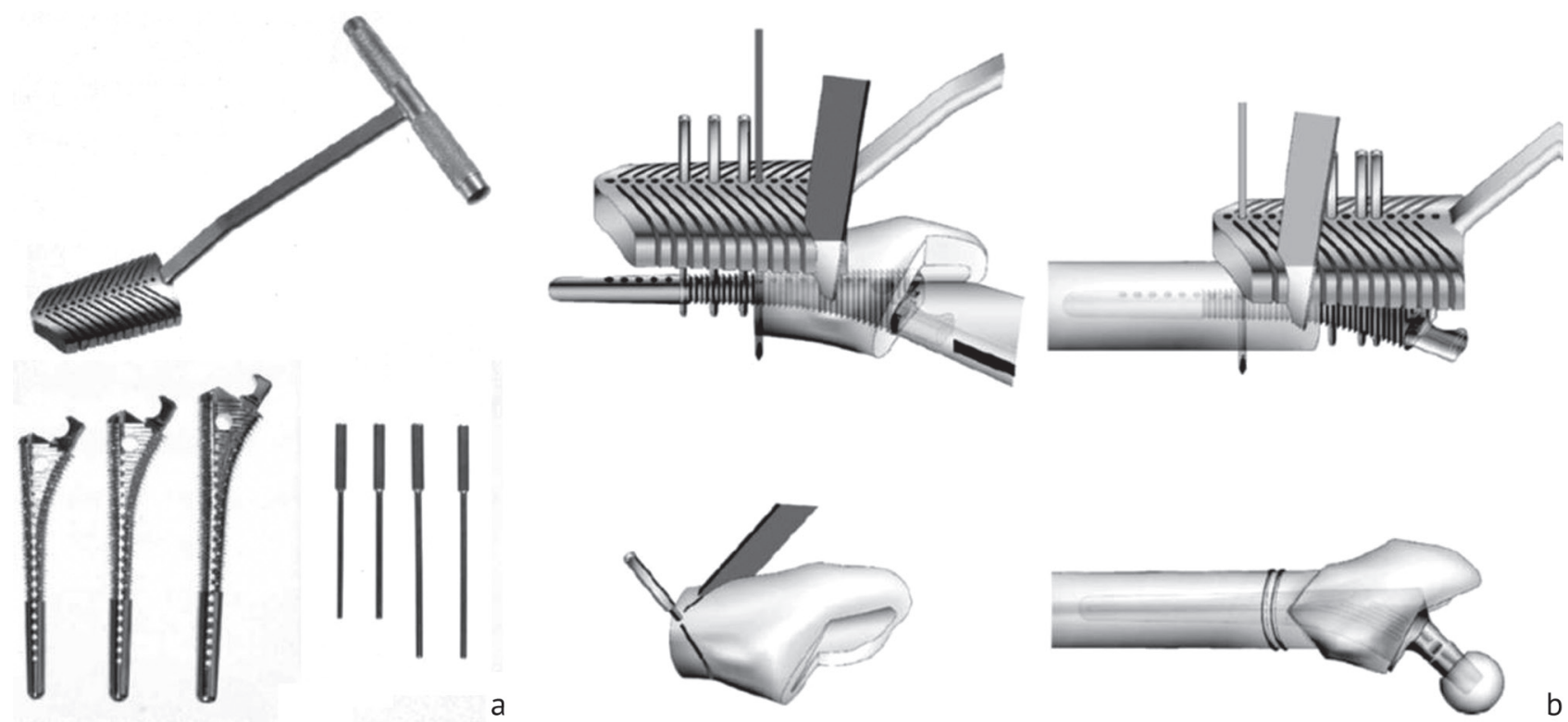

Fig. $2 \boldsymbol{a}$ device for double chevron osteotomy of the femur; $\boldsymbol{b}$ diagram of the osteotomy with application of the device

Table 4

Summary data on the hip joint arthroplasty and combined subtrocanteric shortening osteotomy in high dislocation of the femur

\begin{tabular}{|l|c|c|c|c|}
\hline \multicolumn{1}{|c|}{ Author } & Follow-ups (years) & Number of joints & Nonunion (\%) & Neuropathy (\%) \\
\hline H. Sofu, 2015 [22] & 4.8 & 73 & 5.5 & 0 \\
\hline J. Zhu, 2015 [21] & 3.5 & 21 & 4.7 & 3 \\
\hline M. Ollivier, 2016 [6] & 28 & 10 & 7 & 0 \\
\hline D. Shang, 2016 [27] & 2.7 & 15 & 0 & 13 \\
\hline F. Ozan, 2016 [10] & 5.1 & 32 & 3.1 & 0 \\
\hline A. Can, 2017 [28] & 3.7 & 69 & 1.4 & 4.3 \\
\hline G. Rollo, 2017 [29] & 3.9 & 17 & 0 & 11.7 \\
\hline Mean & $7.3 \pm 2.2$ & $33.8 \pm 8$ & $3.1 \pm 0.8$ & $4.6 \pm 1.7$ \\
\hline
\end{tabular}

The study of Turkish colleagues included 73 arhtroplasties with transverse subtrochanteric osteotomies and bone plating with a cable system in all cases. Consolidation in 66 cases $(94.4 \%)$ was observed after $5.2 \pm 2$ months [22].

Rollo et al obtained consolidation in all their patients after 4.5 months. Despite the shortening osteotomy performed, neuropathy happened in $11.7 \%$ of cases. Relative shortening prior to the intervention was $4.5 \mathrm{~cm}(\min -3.8 ; \max -7.0 \mathrm{~cm})$ and corresponds to the initial shortening in our patients [29].

There were two cases of nonunion in the whole group (12.5\%), and one (6.25\%) had sciatic nerve lesion due to traction. Thus, the incidence of complications in our study was similar to the data in the studies published.

Limitation of the study is a small number of cases in both groups.

\section{CONCLUSION}

The special device developed for subtrochanteric osteotomy technically simplifies the arthroplasty procedure in patients with high hip dislocation. The results also confirm that the duration of the operation and intraoperative blood loss were lower in the subgroup with the guiding device used than in the control subgroup. Midterm Harris Hip Score results were insignificantly different $(p>0,05)$. Further study of treatment outcomes in a larger group of patients is needed.

\section{Conflict of interests None}

\section{REFERENCES}

1. Tikhilov R.M., Mazurenko A.V., Shubniakov I.I., Denisov A.O., Blizniukov V.V., Bilyk S.S. Rezultaty endoprotezirovaniia tazobedrennogo sustava s ukorachivaiushchei osteotomiei po metodike T. Paavilainen pri polnom vyvikhe bedra [Results of the hip arthroplasty with shortening osteotomy according to T. Paavilainen technique for complete dislocation of the hip]. Travmatologiia i Ortopediia Rossii, 2014, no. 1 (71), pp. 5-15. (in Russian)

2. Ahmed E., Ibrahim El-G., Ayman B. Total hip arthroplasty with subtrochanteric osteotomy in neglected dysplastic hip. Int. Orthop., 2015, vol. 39, no. 1 , pp. 27-33. DOI: $10.1007 / \mathrm{s} 00264-014-2554-0$ 
3. Liu T., Wang S., Huang G., Wang W. Treatment of Crowe IV developmental dysplasia of the hip with cementless total hip arthroplasty and shortening subtrochanteric osteotomy. J. Int. Med. Res., 2019, vol. 47, no. 7, pp. 3223-3233. DOI: 10.1177/0300060519853383

4. Oinuma K., Tamaki T., Miura Y., Kaneyama R., Shiratsuchi H. Total hip arthroplasty with subtrochanteric shortening osteotomy for Crowe grade 4 dysplasia using the direct anterior approach. J. Arthroplasty, 2014, vol. 29, no. 3, pp. 626-629. DOI: 10.1016/j.arth.2013.07.038

5. Zagra L., Bianchi L., Mondini A., Ceroni R.G. Oblique femoral shortening osteotomy in total hip arthroplasty for high dislocation in hip with dysplasia. Int. Orthop., 2015, vol. 39, no. 9, pp. 1797-1802. DOI: 10.1007/s00264-015-2865-9

6. Ollivier M., Abdel M.P., Krych A.J., Trousdale R.T., Berry D.J. Long-term results of total hip arthroplasty with shortening subtrochanteric osteotomy in Crowe IV developmental dysplasia. J. Arthroplasty, 2016, vol. 31, no. 8, pp. 1756-1760. DOI: 10.1016/j.arth.2016.01.049

7. Mu W., Yang D., Xu B., Mamtimin A., Guo W., Cao L. Midterm outcomes of cementless total hip arthroplasty in Crowe IV-Hartofilakidis Type III developmental dysplasia of the hip. J. Arthroplasty, 2016, vol. 31, no. 3, pp. 668-675. DOI: 10.1016/j.arth.2015.10.011

8. Mazurenko A.V., Tikhilov R.M., Shubniakov I.I., Nikolaev N.S., Pliev D.G., Blizniukov V.V. Otsenka vozmozhnosti vosstanovleniia dliny konechnosti u patsientov s tiazheloi stepeniu displazii tazobedrennogo sustava pri razlichnykh variantakh khirurgicheskoi tekhniki endoprotezirovaniia [Evaluation of the possibility of limb length restoration in patients with the hip dysplasia of severe degree for different variants of surgical arthroplasty technique]. Travmatologiia i Ortopediia Rossii, 2010, no. 3 (57), pp. 16-20. (in Russian)

9. Greber E.M., Pelt C.E., Gililland J.M., Anderson M.B., Erickson J.A., Peters C.L. Challenges in Total Hip Arthroplasty in the Setting of Developmental Dysplasia of the Hip. J. Arthroplasty, 2017, vol. 32, no. 9S, pp. S38-S44. DOI: 10.1016/j.arth.2017.02.024

10. Ozan F., Uzun E., Gürbüz K., Koyuncu Ş., Altay T., Kayali C. Total hip arthroplasty in the developmental dysplasia of the hip using transverse subtrochanteric osteotomy. J. Orthop., 2016, vol. 13, no. 4, pp. 259-263. DOI: 10.1016/j.jor.2016.06.010

11. Grappiolo G., La Camera F., Della Rocca A., Mazziotta G., Santoro G., Loppini M. Total hip arthroplasty with a monoblock conical stem and subtrochanteric transverse shortening osteotomy in Crowe type IV dysplastic hips. Int. Orthop., 2019, vol. 43, no. 1, pp. 77-83. DOI: 10.1007/ s00264-018-4122-5

12. Paavilainen T., Hoikka V., Paaovolainen P. Cementless total hip arthroplasty for congenitally dislocated or dysplastic hips. Technique for replacement with a straight femoral component. Clin. Orthop. Relat. Res., 1993, no. 297, pp. 71-81.

13. Thorup B., Mechlenburg I., Soballe K. Total hip replacement in the congenitally dislocated hip using the Paavilainen technique: 19 hips followed for 1,5-10 years. Acta Orthop., 2009, vol. 80, no. 3, pp. 259-262. DOI: 10.3109/17453670902876789

14. Hasegawa Y., Iwase T., Kanoh T., Seki T., Matsuoka A. Total hip arthroplasty for Crowe type IV developmental dysplasia. J. Arthroplasty, 2012, vol. 27 , no. 9, pp. 1629-1635. DOI: 10.1016/j.arth.2012.02.026

15. Koulouvaris P., Stafylas K., Sculco T., Xenakis T. Distal femoral shortening in total hip arthroplasty for complex primary hip reconstruction. A new surgical technique. J. Arthroplasty, 2008, vol. 23, no. 7, pp. 992-998. DOI: 10.1016/j.arth.2007.09.013

16. Akhmedov B.G., TkachevA.A., Chililov A.A. Korrigiruiushchaia osteotomiia bedrennoi kosti v kompleksnom lechenii patsientov s vysokim vyvikhom bedrennoi kosti [Correcting osteotomy of the femur in complex treatment of patients with high dislocation of the hip]. Vysokotekhnologichnaia Meditsina, 2016, no. 4, pp. 20-28. (in Russian)

17. Kiliçoğlu O., Türker M., Akgül T., Yazicioğlu O. Cementless total hip arthroplasty with modified oblique femoral shortening osteotomy in Crowe type IV congenital hip dislocation. J. Arthroplasty, 2013, vol. 28, no. 1, pp. 117-125. DOI: 10.1016/j.arth.2012.06.014

18. Tacao M., Ohzono K., Nishii T., Miki H., Nokamura N., Sugano N. Cementless modular total hip arthroplasty with subtrochanteric shortening osteotomy for hips with developmental dysplasia. J. Bone Joint Surg. Am., 2011, vol. 93-A, no. 6, pp. 548-555.

19. Li C., Zhang C., Zhang M., Ding Y. Comparison of transverse and modified subtrochanteric femoral shortening osteotomy in total hip arthroplasty for developmental dysplasia of hip: a meta-analysis. BMC Musculoskelet. Disord., 2014, vol. 15, pp. 331. DOI:10.1186/1471-2474-15-331

20. Kamshilov B.V., Triapichnikov A.S., Chegurov O.K., Zhdanov A.S., Zaitseva O.P. Osobennosti endoprotezirovaniia tazobedrennogo sustava u bolnykh s vysokim vyvikhom bedra [Special characteristics of the hip arthroplasty in patients with high dislocation of the hip]. Travmatologiia $i$ Ortopediia Rossii, 2017, vol. 23, no. 4, pp. 39-47. (in Russian) Available at: https://doi.org/10.21823/2311-2905-2017-23-4-39-47

21. Zhu J., Shen C., Chen X., Cui Y., Peng J., Cai G. Total hip arthroplasty with a non-modular conical stem and transverse subtrochanteric osteotomy in treatment of high dislocated hips. J. Arthroplasty, 2015, vol. 30, no. 4, pp. 611-614. DOI: 10.1016/j.arth.2014.11.002

22. Sofu H., Kockara N., Gursu S., Issin A., Oner A., Sahin V. Transverse subtrochanteric shortening osteotomy during cementless total hip arthroplasty in Crowe type-III or IV developmental dysplasia. J. Arthroplasty, 2015, vol. 30, no. 6, pp. 1019-1023. DOI: 10.1016/j.arth.2015.01.045

23. Li L., Yu M., Yang C., Gu G. Total hip arthroplasty (S-ROM stem) and subtrochanteric osteotomy for Crowe type IV developmental dysplasia of the hip. Indian J. Orthop., 2016, vol. 50, no. 2, pp. 195-200. DOI: 10.4103/0019-5413.177575

24. Wang D., Li L.L., Wang H.Y., Pei F.X., Zhou Z.K. Long-term results of cementless total hip arthroplasty with shortening subtrochanteric shortening osteotomy in Crowe Type IV developmental dysplasia. J. Arthroplasty, 2017, vol. 32, no. 4, pp. 1211-1219. DOI: 10.1016/j.arth.2016.11.005

25. Erdemli B., Yilmaz C., Atalar H., Güzel B., Cetin I. Total hip arthroplasty in developmental high dislocation of the hip. J. Arthroplasty, 2005, vol. 20, no. 8, pp. 1021-1028. DOI: $10.1016 /$ j.arth.2005.02.003

26. Hotokebuchi T., Sohonata M., Shigematsu M., Mawatari M. A new device for a V-shaped subtrochanteric osteotomy combined with total hip arthroplasty. J. Arthroplasty, 2006, vol. 21, no. 1, pp. 135-137. DOI: 10.1016/j.arth.2005.10.009

27. Shang D.C., Zhong S.C., Zhang X.Z., Lu D.P., Lui Q.L. Surgical treatment for osteoarthritis secondary to Crowe type IV developmental dysplasia of hip in adults. Zhongguo Gu Shang., 2016, vol. 29, no. 2, pp. 125-130.

28. Can A., Sarikaya I.A., Yontar N.S., Erdogan A.O., Gorgun B., Erdogan F. High-riding congenital hip dislocation: THA with unilateral vs bilateral transverse femoral shortening osteotomy. J. Arthroplasty, 2017, vol. 33, no. 5, pp. 1432-1436. DOI: 10.1016/j.arth.2017.11.067

29. Rollo G., Solarino G., Vicenty G., Picca G., Garrozzo M., Moretti B. Subtrochanteric femoral shortening osteotomy combined with cementless total hip replacement for Crowe type IV developmental dysplasia: a retrospective study. J. Orthop. Traumatol., 2017, vol. 18, no. 4, pp. 407-413. DOI: 10.1007/s10195-017-0466-7

Received: 21.04 .2020

Information about the authors:

1. Aleksandr S. Triapichnikov, M.D., Ph.D.,

Ilizarov National Medical Research Centre for Orthopaedics and Traumatology, Kurgan, Russian Federation, Email: pich86@bk.ru

2. Boris V. Kamshilov, M.D., Ph.D.,

Ilizarov National Medical Research Centre for Orthopaedics and Traumatology, Kurgan, Russian Federation, Email: bkamshilov@mail.ru

3. Olga P. Zaitseva, M.D., Ph.D., Ilizarov National Medical Research Centre for Orthopaedics and Traumatology, Kurgan, Russian Federation, Email: olakovalenko@yandex.ru
4. Oleg K. Chegurov, M.D., Ph.D., Ilizarov National Medical Research Centre for Orthopaedics and Traumatology, Kurgan, Russian Federation

5. Yana V. Evreinova, M.D., Ilizarov National Medical Research Centre for Orthopaedics and Traumatology, Kurgan, Russian Federation, Email: yana-mamrova@mail.ru

6. Marina Yu. Frashko, M.D.,

Ilizarov National Medical Research Centre for Orthopaedics and Traumatology, Kurgan, Russian Federation, Email: Frashko@list.ru 